Artigo / Article

\title{
Erythrocyte indices and serum ferritin in newborns
}

\section{Indices de eritrócitos e ferritina sérica em recém-nascidos}

\author{
Maria de Fatima Pussick Nunes ${ }^{I}$ \\ Ana Marlúcia Oliveira Assis ${ }^{2}$ \\ Sandra Maria Conceição Pinheiro ${ }^{3}$ \\ Fabiola Eloy da Rocha Medrado ${ }^{4}$
}

\begin{abstract}
Hematological values for newborn babies differ depending on the gestational age and intrauterine growth. However, information in published studies about hematological values for cord blood according to weight-for-gestational-age categories is limited and inconsistent, especially regarding small-for-gestational-age (SGA) newborns. With the aim of describing hematological values for umbilical cord blood, we conducted a cross-sectional study in two government maternity hospitals in Salvador, Brazil. Eighty-eight healthy, term, appropriate-for-gestational-age (AGA), 23 term, smallfor-gestational-age (SGA), and 13 preterm, AGA newborns were studied. Means and standard deviation, and maximum and minimum values were used to describe the level of hemoglobin (Hb), red blood cells (RBC), hematocrit (HCT), mean corpuscular volume (MCV), mean corpuscular hemoglobin $(M C H)$, red cell distribution width $(R D W)$ and serum ferritin. The highest values of RBC, Hb, HCT and serum ferritin were recorded for term $S G A$ newborns and the lowest values were recorded for preterm AGA newborns. Term AGA newborns had intermediate values for all these parameters. In this study we observed the highest hematological values in SGA newborns. Because, these infants are at the highest risk of iron deficiency, the use of more detailed screening tests for iron deficiency in these newborns at birth, using a combination of biomarkers, should be considered.
\end{abstract}

Keywords: Infant; Small for gestational age; Fetal blood; Erythrocyte indices; Ferritins

\section{Introduction}

At birth, hematological values are higher when compared to those observed in older children or adults. This is in response to increased erythropoiesis caused by intrauterine hypoxia. ${ }^{(1)}$ In addition, hematological values in newborns vary according to gestational age and fetal growth. Some investigators have reported term, small-for-gestationalage (SGA) newborns as having higher levels of hemoglobin $(\mathrm{Hb})$, red blood cells $(\mathrm{RBC})$ and hematocrit $(\mathrm{HCT})$, compared to appropriate-for-gestational-age (AGA) newborns. ${ }^{(2-5)}$
Furthermore, studies have reported lower values for preterm AGA newborns. ${ }^{(3,6)}$

Reference hematological values for cord blood have not been standardized, and routinely out of date values proposed in the literature are used.(7) In published studies, information on hematological values in cord blood is limited and inconsistent. The studies that we found ${ }^{(3-6,8-10)}$ evaluated different subgroups of neonates and different hematological parameters. In particular, little data regarding hematological parameters of SGA newborns was found. ${ }^{(3-5,9)}$ However, the impaired fetal growth and/or the condition of SGA are

Instituto de Saúde Coletiva, Universidade Federal da Bahia, UFBA, Salvador (BA), Brazil.

${ }^{1}$ ESL/Science Department, North High School. Phoenix, AZ, USA.

${ }^{2}$ Escola de Nutrição, Universidade Federal da Bahia, UFBA, Salvador (BA), Brazil.

${ }^{3}$ Centro de Ciências Exatas e Tecnológicas - Cetec - Universidade Federal do Recôncavo da Bahia - UFRB - Cruz das Almas (BA), Brazil.

${ }^{4}$ Instituto de Perinatologia da Bahia - Iperba - Salvador (BA), Brazil.

Conflict of interest: none

Correspondence: Maria de Fátima Pussick Nunes

8210 S. 34th Dr. Laveen, AZ 85339, U.S.A.

Phone: 1(602) 702-1327

E-mail:pussick@hotmail.com 
associated with increased infant mortality and various morbidities, including hematological changes.

Hence, the objective of this study was to describe the hematological profile of umbilical cord blood and iron reserve in three distinct groups of newborn babies: term AGA, term SGA and the preterm AGA; and to compare these results with those reported by other authors.

\section{Methods}

This is a descriptive, cross-sectional study of 124 newborns at two government maternity hospitals in Salvador, Bahia, Brazil. Newborns were prospectively and consecutively enrolled between June 2005 and October 2006. We included all newborns delivered vaginally or by cesarean, born at $\geq 30$ and $\leq 41$ weeks of gestation. They were divided into three groups: Group 1 (the controls): eighty-eight healthy, term (gestational age $\geq 37$ and $\leq 41$ weeks), AGA newborns (birth weight $\geq 10$ th and $<90$ th percentile). Group 2: twentythree term, SGA newborns. Group 3: thirteen preterm (birth weight $<37$ weeks), AGA newborns. Small-for-gestationalage was defined as birth weight $<10$ th percentile for gestational age. ${ }^{(11)}$

Newborns were excluded if they were large for gestational age (birth weight $\geq 90$ th), were multiple births or had chromosomal anomalies, intrapartum complications or hemoglobinopathies. In addition, newborns with low Apgar scores $(\leq 7)$ within the first five minutes and those whose mothers had Rh-negative blood were excluded from the control group.

This study was approved by the Ethics Committee of the "Instituto de Saúde Coletiva - Universidade Federal da Bahia" (Institute of Community Health - Bahia Federal University). Informed written consent was obtained from all mothers and all interviews were carried out post delivery, with mothers in good clinical conditions. Mothers with SGA newborns were notified and counseled about the need for further clinical evaluations.

Birth weight was collected from medical records. Gestational age was defined in full completed weeks ${ }^{12}$ and measured by the three following methods, according to the best antenatal data provided:

Last Menstrual Period Method (LMP) - This was the primary method for defining gestational age, if the LMP was known and menstrual cycle was regular (25-31days). ${ }^{(12)}$ This information was obtained from medical records and confirmed by interview.

Ultrasound Method - Given the potential problems of the LMP method (maternal recall and/or early, nonmenstrual bleeding, wrongly interpreted as a period), ${ }^{(12-14)}$ we used the ultrasound method when an accurate LMP was unknown or the menstrual cycle was irregular. Only early ultrasound measurement ( $<10$ weeks) of the crown-rump length or $(<20$ weeks $)$ of the biparietal diameter or femur (diaphysis) length were used. All of them are considered good standards. ${ }^{(13,15)}$ This information was obtained from medical records. If the record could not be found, we requested a copy of test results directly from the patient.

Capurro Method (physical) - In the absence of information about LMP and ultrasound, the Capurro method $^{(16)}$ was used, regardless of its limitations. ${ }^{(17-19)}$ This information was obtained from medical records. When the information from the three previously noted methods was unavailable, the Capurro method was performed by trained interviewers. The interviewers evaluated 4 newborns.

Blood Sampling - Blood samples were collected from the umbilical cord. In all cases the placental cord was clamped immediately after delivery. Two blood samples, consisting of $5 \mathrm{ml}$ each, were collected. The blood samples were kept refrigerated and sent immediately for processing. One sample with ethylenediaminetetraacetic acid (EDTA) was sent for complete blood count and for diagnosis of hemoglobinopathies. The second sample was used to evaluate the serum ferritin.

Hematological Analyses were performed with a Pentra Retic 80 Horiba/ABX coulter analyzer. The following hematologic parameters were determined: hemoglobin $(\mathrm{Hb})$, red blood cells (RBC), hematocrit (HCT), mean corpuscular volume (MCV), mean corpuscular hemoglobin $(\mathrm{MCH})$ and red cell distribution width (RDW).

Ferritin was measured by the radioimmunoassay (RIA) technique (IMIX Ferritin) using Access Immunoassay Systems (Imunosystems) equipment from Abbot Laboratories-USA.

Evaluation of hemoglobinopathies was carried out by High Performance Liquid Chromatography (HPLC), by ßThalassemia Short Program on the Bio-Rad Variant, HPLC Analyzer System (Bio-Oxford Ltd).

Maternal Characteristics - The following maternal data were collected through standardized pre-coded questionnaires, that were completed in face-to-face interviews: Socioeconomic Status - was defined according to the Criteria of the Economic Classification in Brazil (Critério de Classificação Econômica Brasil - CCEB) ${ }^{(20)}$ as proposed by the Brazilian Association of Survey Companies (Associação Brasileira de Empresas de Pesquisa-ABEP). According to these criteria, seven categories were established: Groups A1 and A2 (high), Groups B1 and B2 (intermediate), Group C (intermediate-low), Group D (low) and Group E (very low). Given the small numbers in groups $\mathrm{A}$ and $\mathrm{B}$, and for analysis purposes, it was decided to group these categories into group $\mathrm{C}$. Therefore, the Groups A, B, and C were renamed Group C (reference category).

Color/race - was classified in accordance with the categories of white, brown (mulatto), black, yellow, and indigenous. These categories were proposed by the Brazilian Institute for Geography and Statistics (Instituto Brasileiro de Geografia e Estatística - IBGE) ${ }^{(21)}$ based on self-classification. 
The interviewee had to answer the question, "What is your color or race?" and was asked to choose one of the above mentioned options. Due to the small number of samples in the categories of "yellow" and "indigenous," these two categories were placed into the existing "mulatto" category. These three categories, mulatto, yellow and indigenous, were then renamed as "others." White color/race was adopted as the reference category in order to compare against the categories of "black" and "others." In addition, maternal information on age, smoking, and method of delivery were collected.

\section{Statistical analysis}

Descriptive analysis was carried out using the statistical software package SPSS, version 11.0 (SPSS Inc, Chicago, IL). The study used means and standard deviation and both maximum and minimum values to describe the hematologic parameters.

\section{Results}

\section{Sample characteristics}

All newborns tested for hemoglobinopathies were normal and therefore none was excluded for this condition. Out of 124 newborns selected for this study, $46 \%$ were male. The mean gestational age for term newborns was $39.42 \pm$

Table 1. Maternal characteristics according to the newborn babies' weightfor-gestational-age-category at two government maternity hospitals in Salvador

\begin{tabular}{|c|c|c|c|c|}
\hline \multirow[b]{2}{*}{ Maternal characteristics } & \multicolumn{4}{|c|}{ Newborns } \\
\hline & Term AGA & Term SGA & Preterm AGA & Total \\
\hline & $\mathrm{n}(\%)$ & $\mathrm{n}(\%)$ & $\mathrm{n}(\%)$ & $\%$ \\
\hline \multicolumn{5}{|l|}{ Color/Race ${ }^{\mathrm{a}}$} \\
\hline White & $13(14.8)$ & $3(13.1)$ & $2(15.4)$ & 14.5 \\
\hline Black & $39(44.3)$ & $11(47.8)$ & $4(30.8)$ & 44.4 \\
\hline Other & $36(40.9)$ & $9(39.1)$ & $7(53.8)$ & 41.1 \\
\hline \multicolumn{5}{|l|}{ Age (years) } \\
\hline$<20$ & $12(13.6)$ & $4(17.4)$ & $2(15.4)$ & 14.6 \\
\hline $20-35$ & $66(75.0)$ & $18(78.3)$ & $8(61.5)$ & 74.8 \\
\hline 35 & $10(11.4)$ & $1(4.3)$ & $3(23.1)$ & 10.6 \\
\hline \multicolumn{5}{|l|}{ Socioeconomic status } \\
\hline Intermediate & $43(48.9)$ & $11(47.8)$ & $8(61.5)$ & 50.0 \\
\hline Low & $43(48.9)$ & $9(39.1)$ & $4(30.8)$ & 46.0 \\
\hline Very low & $2(2.2)$ & $3(13.1)$ & $1(7.7)$ & 4.0 \\
\hline \multicolumn{5}{|l|}{ Smoker } \\
\hline No & $83(94.3)$ & $19(82.6)$ & $10(76.9)$ & 90.3 \\
\hline Yes & $5(5.7)$ & $4(17.4)$ & $3(23.1)$ & 9.7 \\
\hline \multicolumn{5}{|l|}{ Method of delivery } \\
\hline Vaginal & $60(68.2)$ & $19(82.6)$ & $6(50.0)$ & 69.1 \\
\hline Cesarean & $28(31.8)$ & $4(17.4)$ & $7(50.0)$ & 30.9 \\
\hline \multicolumn{5}{|l|}{ Iron supplementation } \\
\hline Yes & $63(71.6)$ & $17(73.9)$ & $10(76.9)$ & 72.6 \\
\hline No & $25(28.4)$ & $6(26.1)$ & $3(23.1)$ & 27.4 \\
\hline
\end{tabular}

1.21 weeks, and for preterm babies was $34.69 \pm 2.29$ weeks. Mean birth weights were $3290.55 \pm 300.52 \mathrm{~g}$ for term, AGA newborns; $2583.26 \pm 271.99 \mathrm{~g}$ for term, SGA newborns and $2533.08 \pm 754.95 \mathrm{~g}$ for preterm, AGA newborns (data not shown). Table 1 presents some of the selected maternal characteristics. According to this table, most of the mothers classified themselves as black (44.4\%). The socioeconomic status was mainly intermediate (50.0\%) and low (46.0\%). Most of them had not smoked $(90.3 \%)$, and had taken iron supplements during pregnancy $(72.6 \%)$.

\section{Capurro method}

We evaluated the reliability of the Capurro method performed by interviewers. The intraclass correlation coefficient (ICC) was calculated in five percent of the sample, and there was no evidence of inter-observer variability $(\text { rho }=0)^{(22)}$ (data not shown).

\section{Hematologic parameters}

Hematologic parameters of umbilical cord blood are presented in Table 2. Mean values for RBC were higher in term, SGA newborns $\left(4.46 \times 10^{12} / 1 \pm 0.49\right)$; slightly lower in term $\mathrm{AGA}\left(4.21 \times 10^{12} / 1 \pm 0.48\right)$; and even lower in preterm AGA $\left(4.00 \times 10^{12} / 1 \pm 0.52\right)$. Similar patterns were observed for $\mathrm{Hb}$ and Hct. Term SGA newborns presented the highest mean values, with $\mathrm{Hb}$ at $15.07 \mathrm{~g} / \mathrm{dl} \pm 1.26$ and $\mathrm{Hct}$ at $45.33 \%$ \pm 3.73 . Preterm AGA newborns presented the lowest values, with $\mathrm{Hb}$ at $14.26 \mathrm{~g} / \mathrm{dl} \pm 1.94$ and $\mathrm{Hct}$ at $42.56 \% \pm 5.78$.

$\mathrm{MCV}$ and $\mathrm{MCH}$ exhibited a different pattern. Preterm AGA newborns showed the highest mean values, $106.30 \mathrm{fl}$ \pm 3.52 and $35.53 \mathrm{pg} \pm 1.38$, respectively. Term SGA newborns showed the lowest mean values, with MCV at $102.08 \mathrm{fl} \pm 7.08$ and $\mathrm{MCH}$ at $33.91 \mathrm{pg} \pm 2.69$.

The mean values of RDW were similar in the different groups of newborns (Table 2). Term SGA newborns presented a slightly higher mean value $(13.56 \%$ $\pm 0.70)$ than term AGA and preterm AGA newborns (13.33\% \pm 0.85 and $13.38 \% \pm 0.86$, respectively). Term SGA newborns also presented the highest mean values for serum ferritin $(190.89 \mu \mathrm{g} / 1 \pm 144.79)$ and preterm AGA newborns presented the lowest $(142.23 \mu \mathrm{g} / 1 \pm 65.55)$.

\section{Discussion}

In this study, we observed that term, SGA newborns presented the highest mean values for $\mathrm{Hb}, \mathrm{RBC}$, Hct and ferritin and preterm, AGA newborns exhibited the lowest mean values for these parameters. Preterm, AGA newborns however, presented the highest mean values for MCV and $\mathrm{MCH}$. Term AGA newborns showed intermediate values for all these parameters (Table 2). Higher mean values for $\mathrm{Hb}, \mathrm{RBC}$ and Hct, in term SGA newborns compared to other newborns, have previously been reported in other studies. ${ }^{(3-5)}$ It is known that chronic fetal hypoxia, due to poor placental function in 
Table 2. Hematological values of umbilical cord blood according to Newborn babies' weight-for-gestational-age-category at two government maternity hospitals in Salvador

\begin{tabular}{|c|c|c|c|c|c|c|c|}
\hline Newborn group* & $\begin{array}{c}\mathrm{RBC} \\
\left(\mathrm{x} 10^{12} / 1\right)\end{array}$ & $\begin{array}{c}\mathrm{Hb} \\
(\mathrm{g} / \mathrm{dL})\end{array}$ & $\begin{array}{r}\mathrm{HCT} \\
(\%) \\
\end{array}$ & $\begin{array}{l}\mathrm{MCV} \\
\text { (fl) }\end{array}$ & $\begin{array}{r}\mathrm{MCH} \\
(\mathrm{Pg}) \\
\end{array}$ & $\begin{array}{c}\text { RDW } \\
(\%)\end{array}$ & $\begin{array}{c}\text { Serum ferritin } \\
(\mathrm{mg} / \mathrm{L})\end{array}$ \\
\hline $\begin{array}{c}\text { Term AGA } \\
\mathrm{n}=88\end{array}$ & $\begin{array}{l}4.210 .48 \\
(3.24-5.89)\end{array}$ & $\begin{array}{c}14.501 .42 \\
(11.50-18.30)\end{array}$ & $\begin{array}{c}43.504 .36 \\
(33.50-54.40)\end{array}$ & $\begin{array}{c}103.665 .30 \\
(89.00-115.00)\end{array}$ & $\begin{array}{cc}34.52 & 2.11 \\
(30.00-39.00)\end{array}$ & $\begin{array}{c}13.330 .85 \\
(11.80-16.20)\end{array}$ & $\begin{array}{l}162.61100 .10 \\
(14.45-577.90)\end{array}$ \\
\hline $\begin{array}{c}\text { Term SGA } \\
\mathrm{n}=23\end{array}$ & $\begin{array}{l}4.460 .49 \\
(3.56-5.35)\end{array}$ & $\begin{array}{c}15.071 .26 \\
(12.60-17.50)\end{array}$ & $\begin{array}{c}45.333 .73 \\
(37.60-52.60)\end{array}$ & $\begin{array}{c}102.08 \quad 7.08 \\
(84.0-110.00)\end{array}$ & $\begin{array}{c}33.912 .69 \\
(27.20-37.00)\end{array}$ & $\begin{array}{c}13.560 .70 \\
(12.30-15.30)\end{array}$ & $\begin{array}{l}190.89144 .79 \\
(55.11-680.40)\end{array}$ \\
\hline $\begin{array}{c}\text { Preterm AGA } \\
n=13\end{array}$ & $\begin{array}{c}4.000 .52 \\
(3.17-4.88)\end{array}$ & $\begin{array}{c}14.261 .94 \\
(11.70-17.80)\end{array}$ & $\begin{array}{c}42.565 .78 \\
(34.60-53.00)\end{array}$ & $\begin{array}{c}106.30 \quad 3.52 \\
(101.00-113.00)\end{array}$ & $\begin{array}{cc}35.53 & 1.38 \\
(33.00-38.00)\end{array}$ & $\begin{array}{c}13.380 .86 \\
(11.50-14.60)\end{array}$ & $\begin{array}{c}142.2365 .55 \\
(39.53-240.80)\end{array}$ \\
\hline
\end{tabular}

SGA newborns with subsequent increases in erythropoiesis, is responsible for this. ${ }^{(14)}$

Our findings of low mean values for $\mathrm{Hb}, \mathrm{RBC}$, Hct, and high mean values for MCV observed in preterm AGA newborns, are similar with those reported by other authors. ${ }^{(3,6)}$ These characteristics of preterm newborns are related to physiologic immaturity of the erythropoietic system. ${ }^{(23,24)}$

We evaluated serum ferritin levels at birth as an indicator of iron deposits in newborns. Fetal iron deposit is related to size at birth and gestational length. The average iron content at birth is approximately $75 \mathrm{mg} / \mathrm{kg}$ of body weight, with storage occurring mostly during the third trimester of gestation. ${ }^{(24)}$ Despite the fact that, infants with intrauterine growth restriction (IUGR) are at risk of iron deficiency, ${ }^{(25)}$ term SGA newborns in this study presented the highest mean values for serum ferritin, different to the results of a previous study. ${ }^{4}$ Low serum ferritin values are good indicators of iron deficiency; high values in contrast, are usually associated with inflammation/infection and frequently associated with IUGR. $^{(24,26)}$

In fact, serum ferritin may not be the appropriate indicator of iron deposit in SGA newborns; however there is no standard test for the diagnosis of iron status at birth ${ }^{(27)}$ and, in this case, a combination of different tests would be appropriate.

Preterm AGA newborns, however, exhibited the lowest mean values of serum ferritin, similar to what was previously reported, ${ }^{(6)}$ and this is mainly related to their low iron deposit. $^{(24)}$

Our study also evaluated RDW. This parameter is a useful tool in the diagnosis of iron status, because it is the first to increase in the presence of iron depletion, followed by the decrease of $\mathrm{MCH}$ and $\mathrm{MCV}$. Therefore, these three parameters have been used in the diagnosis of anemia. ${ }^{(28,29)}$ In this study, mean values of RDW were similar in different groups of newborns, as reported in a previous study. ${ }^{(5)}$

We compared our findings, in term AGA newborns, to those obtained in others studies that had evaluated hematological parameters in cord blood. Some of them classified newborns according to their weight-for-gestational- age-categories $^{(3,5,9)}$ while others did not. ${ }^{(6-8,10)}$ Our results regarding $\mathrm{RBC}$ parameters were similar to those reported in some studies $^{(3,8,10)}$ and lower than those observed in others. ${ }^{(5,6,9)}$ We also observed that our results were lower than those usually used as reference standards in neonatology. ${ }^{(7)}$

We found three probable explanations for the observed differences. One explanation is probably due to the fact that, in this study, we used term AGA newborns as a reference standard instead of term newborns. It is well known that differences exist in hematological parameters of newborns according to their weight-for-gestational-age categories. A second explanation is that, RBC parameters are lower when placental cord is clamped immediately after delivery, ${ }^{(30)}$ which was the case in this study. Finally, an additional explanation may be related to the fact that $44.4 \%$ of the newborns were from mothers that classified themselves as black. In this population group, the hematological values are lower compared to the other groups. ${ }^{(31,32)}$

Comparing our findings regarding serum ferritin levels in term AGA newborns, with those obtained previously, we observed that they were close to the results reported by some authors ${ }^{(6)}$ and higher than those obtained by others. ${ }^{(4,10)}$ The mean value for serum ferritin in term AGA newborns in this study $(162.61 \pm 100.10 \mu \mathrm{g} / \mathrm{l})$, was in agreement with the literature, ${ }^{25}$ and it is probably related to the fact that $72.6 \%$ of mothers took iron supplements during pregnancy.

Our study presented some limitations. Given the small sample of some groups of newborns, especially the preterm AGA group, we did not perform statistical tests to compare mean values of hematological parameters among different groups of newborns. Another limitation was that we did not perform PCR tests to validate the values of serum ferritin, especially in SGA newborns (190.89 \pm 144.79$)$. In addition, there are some limitations specific to each method of gestational age used. However, despite all these limitations, the study shows the hematological parameters in cord blood and identifies the profile of these parameters in SGA newborns, for which the data are limited. We recommend further studies regarding hematological parameters and 
screening for iron deficiency in newborns, according to the weight-for-gestational-age categories, using a combination of biomarkers.

\section{Resumo}

Valores hematológicos dos recém-nascidos (RN) diferenciam-se em função da idade gestacional e do crescimento intrauterino. $\mathrm{Na}$ literatura, as informações sobre valores hematológicos de acordo com categorias de peso para a idade gestacional em $R N$ são escassas e inconsistentes, especialmente referindo-se a $R N$ pequenos para a idade gestacional (PIG). Para descrever os valores hematológicos do cordão umbilical foi realizado um estudo transversal, em duas maternidades públicas de Salvador, Brasil, envolvendo $88 R N$ a termo adequados para a idade gestacional (AIG), $23 R N$ a termo PIG e 13 RN pré-termo AIG. A média, desvio-padrão (DP), e valor máximo e mínimo foram usados para descrever os níveis de hemoglobina $(\mathrm{Hb})$, número de hemácias $(H m)$, hematócrito (HCT), volume globular médio (VGM), hemoglobina globular média (HGM), amplitude de distribuição das hemácias e ferritina sérica. Os valores mais altos de $\mathrm{Hm}, \mathrm{Hb}$, $H C T$ e ferritina sérica foram identificados nos RN a termo PIG, e os mais baixos foram encontrados nos $R N$ pré-termo AIG. Os RN a termo AIG apresentaram valores intermediários para todos referidos parâmetros eritrocitários. Neste estudo foram observados valores hematológicos mais elevados em $R N$ a termo $P I G$, apesar desses $R N$ apresentarem maior probabilidade de deficiência de ferro; indicando a necessidade de um diagnóstico mais detalhado da deficiência de ferro ao nascer, neste grupo de RN, usando a combinação de vários testes.

Descritores: Recém-nascido pequeno para a idade gestacional; Sangue fetal; Índices de eritrócitos; Ferritinas

\section{Acknowledgements}

We are grateful to: "Conselho Nacional de Desenvolvimento Cientifico e Tecnológico (CNPq), "for providing financial support. Maternities "IPERBA" and "Climério de Oliveira," in Salvador/ Brazil, for allowing data collection. Dr. Maria de Lurdes Pires Nascimento and laboratory "APAE-Salvador," for performing blood tests. Dr. Patrícia Mendes, Neonatologist, for providing training on Capurro Method. Carlos Teles, for assisting with statistical analysis. Mary Krigbaum, Jane McNamara, and Kristopher Seydel for copy editing assistance.

\section{References}

1. Silber M. Anemia no período neonatal. In: Segre CAM, Armellini PA, Marino WT, editors. RN. 4a ed. São Paulo: Sarvier; 1995. p.219-23.

2. Vaz FAC. Anemia do recém-nascido. In: Alves Filho N, Correa MD, editors. Manual de perinatologia. 2a ed. São Paulo: Medsi; 1995. p.880-99.

3. Noguera N, Detarsio G, Perez SM, Bragos IM, Lanza O, Rodriguez $\mathrm{JH}$, et al. Hematologic study of newborn umbilical cord blood. Medicina (B Aires). 1999;59:446-8.

4. Rondó PHC, Tomkins AM. Maternal iron status and intrauterine growth retardation. Trans R Soc Trop Med Hyg. 1999;93(4): 423-6.
5. Ozyürek E, Cetintas S, Ceylan T, Ogüs E, Haberal A, Gürakan B, et al. Complete blood count parameters for healthy, small-forgestational-age, full-term newborns. Clin Lab Haem. 2006;28 (2):97-104.

6. Silber M, Segre CAM, Goldenberg S, Casanova LD. Determinação dos valores hematológicos e das concentrações séricas de ferro e ferritina em sangue do cordão umbilical de recém-nascidos de termo e pré-termo no Hospital Israelita Albert Einsten de São Paulo. Acta Cir Bras. 2000;15(4). Disponível em: http://www. scielo.br/ scielo. [2004, August 22].

7. Oski FA, Naiman JL. Normal hematologic values of the newborn. In: Oski FA, Naiman JL, editors. Hematologic problems of the newborn. 2a ed. Philadelphia: W.B. Saunders; 1982. p. 1-32.

8. Pranke P, Failace RR, Allebrandt WF, Steibel G, Schmidt F, Nardi NB. Hematologic and immunophenotypic characterization of human umbilical cord blood. Acta Haematol. 2001;105(2):71-6. Erratum in: Acta Haematol. 2001;105(4):251.

9. Maconi M, Rolfo A, Cardaropoli S, Brini M, Danise P. Hematologic values in healthy and small for gestational age newborns. Lab Hematol. 2005;11(2):152-6.

10. Diagne I, Archambeaud MP, Diallo D, D'oiron R, Yvart J, Tchernia G. Paramètres érytrocytaires et réserves en fer dans le sang du cordon. Arch Pediatr. 1995;2(3):208-14.

11. Williams R1, Creasy RK, Cunnigham GC, Hawes WE, Norris FD, Tashiro M. Fetal growth and perinatal viability in California. Obstet Gynecol (California). 1982;59(5):624 32.

12. World Health Organization. Physical status: The use and interpretation of anthropometry. Geneva: WHO; 1995. p.12160. Tech Rep Ser. 854.

13. Jorge SM, Gonçalves AL. Avaliação da idade gestacional pelo exame físico-clínico do recém-nascido. In: Alves Filho N, Corrêa MD, editors. Manual de perinatologia. 2a ed. Rio de Janeiro: Medsi; 1995. p.391-404.

14. Ramos JLA, Corradini HB, Vaz FAC. Classificação do recém-nascido: Diagnóstico da idade gestacional e da qualidade de crescimento. In: Marcondes E, editor. Pediatria básica. 8a ed. São Paulo: Sarvier; 1999. p.321-8.

15. Chervenak FA, Gabbe SG. Ultra-sonografia obstétrica: avaliação do crescimento e da anatomia fetal, In: Gabbe SG, Niebyl JR, Simpson Jl, editors. Obstetrícia-Gestações normais \& patológicas. 3a ed. Rio de Janeiro: Guanabara Koogan; 1999. p. 209-10.

16. Capurro H, Konichezky S, Fonseca D, Caldeyro-Barcia R. A simplified method for diagnosis of gestational age in the newborn infant. J Pediatr. 1978;93(1):120-2.

17. Fescina R, Lastra LGL, Navas JP, Bertone AG, Schwarcz RL. Diagnosis of gestational age: evaluation by different methods. Rev Latino Perinat. 1986;6:44-50.

18. Gladys HP, Omar A, Guerrero PB. Efecto del cálculo de la edad gestacional en la clasificación del recién nacido. An Venez Nutr. 1996;9:5-10.

19. Panvini J, Beaujón BO, Gutiérrez A, Borrego M, Aray W, Gómez ML, et al. Validity of the Capurro method in the calculation of the gestational age. Bol Hosp Niños J M de los Rios. 1997; 33(2):55-9.

20. Critério de Classificação Econômica Brasil". Disponível em: http:/ /www.abep.org/codigosguias/ABEP_CCEB_2003.pdf. [2000, July 9].

21. Instituto Brasileiro de Geografia e Estatística. Censo Brasileiro 2000. Rio de Janeiro; 2001.

22. Hosmer DW, Lemeshow S. Applied Logistic Regression. 2a ed. New York: John Willey \& Sons INC; 2000.

23. Vaz FAC. Hematopoese intra-uterina. In: VAZ FAC, editor. Hematologia neonatal. São Paulo: Sarvier; 1980. p.3-5. 
24. Brandalise SR, Matsuda E. Anemias carenciais. In: Marcondes E, editor. Desnutrição intra-uterina e pós-natal. São Paulo: Panamed; 1981. p.397-8.

25. Siddappa AM, Rao R, Long JD, Widness JA, Georgieff MK. The Assessment of newborn iron stores at birth: A review of the literature and standards for ferritin concentrations. Neonatology. 2007;92(2):73-82.

26. Dallman PR. Diagnóstico laboratorial da deficiência de ferro no lactente e na criança pequena. In: Anais Nestlé, editors. Deficiência de ferro no lactente e na criança. Nestlé. 1996;52:18-24.

27. Rao R, Georgieff MK. Iron in fetal and neonatal nutrition. Semin Fetal Neonatal Med. 2007;12(1):54-63.

28. Timothy CE, Dietrich J. The red cell distribution width. J Emerg Med. 1991;9:71-4.

29. Juncá J. Un diagnóstico para la ferropenia. Med Clin(Barc). 2001;116(4):146-9.

30. Silva PH, Hashimoto Y. Interpretação laboratorial do eritrograma. São Paulo: Lovise. 1999. p.75-89.

31. Perry GS, Byers T, Yip R, Margen S. Iron nutrition does not account for the hemoglobin differences between blacks and whites. J Nutr. 1992;122(7):1417-24. Comment in: J Nutr. 1993;123 (3):597-9.

32. Alur P, Devapatla SS, Super DM, Danish E, Stern T, Inagandla R, et al. Impact of race and gestational age on red cell indices in very low birth weight infants. Pediatrics. 2000;106(2):306-10.

Received: $21 / 2 / 2010$

Accepted: 2/8/2010 